\title{
Oxygen isotope record of oceanic and high-pressure metasomatism: a P-T-time-fluid path for the Monviso eclogites (Italy)
}

\author{
Daniela Rubatto $^{1,2} \cdot$ Samuel Angiboust ${ }^{3}$
}

Received: 24 June 2015 / Accepted: 13 October 2015 / Published online: 29 October 2015

(C) Springer-Verlag Berlin Heidelberg 2015

\begin{abstract}
Fluids are considered a fundamental agent for chemical exchanges between different rock types in the subduction system. Constraints on the sources and pathways of subduction fluids thus provide crucial information to reconstruct subduction processes. The Monviso ophiolitic sequence is composed of mafic, ultramafic and minor sediments that have been subducted to $\sim 80 \mathrm{~km}$ depth. In this sequence, both localized fluid flow and channelized fluids along major shear zones have been documented. We investigate the timing and source of the fluids that affected the dominant mafic rocks using microscale $\mathrm{U}-\mathrm{Pb}$ dating of zircon and oxygen isotope analysis of mineral zones (garnet, zircon and antigorite) in high-pressure rocks with variable degree of metasomatic modification. In mafic eclogites, Jurassic zircon cores are the only mineralogical relicts of the protolith gabbros and retain $\delta^{18} \mathrm{O}$ values of $4.5-6 \%$, typical of mantle melts. Garnet and metamorphic zircon that grew during prograde to peak metamorphism display low $\delta^{18} \mathrm{O}$ values between 0.2 and $3.8 \%$, which are likely inherited from high-temperature alteration of the protolith
\end{abstract}

Communicated by Steven Reddy.

Electronic supplementary material The online version of this article (doi:10.1007/s00410-015-1198-4) contains supplementary material, which is available to authorized users.

Daniela Rubatto

daniela.rubatto@anu.edu.au; daniela.rubatto@geo.unibe.ch

1 Research School of Earth Sciences, The Australian National University, Canberra 2601, Australia

2 Present Address: Institute of Geological Sciences, University of Bern, 3012 Bern, Switzerland

3 Helmholtz Centre Potsdam, GFZ German Research Centre for Geosciences, 14473 Potsdam, Germany on the sea floor. This is corroborated by $\delta^{18} \mathrm{O}$ values of 3.0 and $3.6 \%$ in antigorite from surrounding serpentinites. In metasomatized eclogites within the lower shear zone, garnet rim formed at the metamorphic peak shows a shift to higher $\delta^{18} \mathrm{O}$ up to $6 \%$. The age of zircons in high-pressure veins and metasomatized eclogites constrains the timing of fluid flow at high pressure at around 45-46 Ma. Although the oxygen data do not contradict previous reports of interaction with serpentinite-derived fluids, the shift to isotopically heavier oxygen compositions requires contribution from sediment-derived fluids. The scarcity of metasediments in the Monviso sequence suggests that such fluids were concentrated and fluxed along the lower shear zone in a sufficient amount to modify the oxygen composition of the eclogitic minerals.

Keywords Oxygen isotopes - Subduction - Garnet · Zircon $\cdot$ Shear zone $\cdot$ Ophiolite $\cdot$ Ion microprobe

\section{Introduction}

Subduction of oceanic and continental crust is one of the most efficient processes for element exchanges between a crust enriched in incompatible elements and the surrounding mantle. Although melting eventually occurs at ultrahigh-pressure conditions (Hermann et al. 2013), significant subduction metamorphism occurs at sub-solidus conditions, where free fluids serve as catalysts to reactions, and for the dissolution of phases, redistribution of elements and advection of heat (Yardley 2009; Jamtveit and Austrheim 2010). Metamorphic fluids are generally aqueous, highly mobile and buoyant so that they rapidly escape the system with which they have reacted. However, fluids may leave behind distinctive geochemical signatures and, in the best 
cases, fluid inclusions in minerals. Most commonly the traces of escaped fluids are subtle, but when the chemistry of the system is drastically changed by the metamorphic fluids, the term metasomatism applies (see a review of the topic in Harlov and Austrheim 2013).

The geochemical and isotopic signatures preserved within minerals can assist in reconstructing the passage of fluids and the exchanges between different layers of the subducting slab. Elements that are relatively water soluble and that also enter common minerals are naturally targeted as fluid tracers (e.g. $\mathrm{F}, \mathrm{Cl}, \mathrm{B}, \mathrm{Li}$ and $\mathrm{LREE}-\mathrm{La}$ to $\mathrm{Sm}$ ). Oxygen, as the major constituent of aqueous solutions and minerals, is another obvious tracer for fluids, specifically its isotopic composition, which changes according to temperature, fluid sources and minerals involved (Hoefs 2004). In metamorphic systems, different stages of the rock evolution are commonly recorded by distinct mineral zones. Such intracrystalline oxygen isotopes variations are best measured by ion microprobe (Eiler et al. 1995; Vielzeuf et al. 2005; Ayers et al. 2006; Page et al. 2010; Martin et al. 2011, 2014; Raimondo et al. 2012; Errico et al. 2013; Russell et al. 2013; Page et al. 2014).

Two main features make the use of oxygen isotopes in subducted rocks particularly effective. Firstly, the relatively low temperature and fast exhumation of rock units is fundamental in preserving microscale chemical and isotopic heterogeneities from diffusional re-equilibration. Secondly, the subducting slab contains a variety of rock types, each with distinct isotopic signatures from metasediments $\left(\delta^{18} \mathrm{O}=8-26 \%\right.$, Bebout and Barton 1989; Miller et al. 2001), to pristine or altered basalts (5.5$15 \%$, Cartwright and Barnicoat 1999; Miller and Cartwright 2000; Miller et al. 2001), to serpentinites (3.5$12 \%$, Gregory and Taylor 1981; Früh-Green et al. 2001). Significant exchanges of aqueous fluids between rocks types are expected to modify the $\delta^{18} \mathrm{O}$ of the rock. Conventional studies of exhumed high-pressure terranes have used bulk oxygen isotope analysis to reconstruct a picture of the average composition of subducted rocks (e.g. Bebout and Barton 1989; Nadeau et al. 1993; Philippot 1993; Cartwright and Barnicoat 1999; Miller and Cartwright 2000; Miller et al. 2001). Such studies document a limited effect that subduction-related metamorphism has on $\delta^{18} \mathrm{O}$, but have also identified large- and smallscale fluid exchanges and metasomatism that can significantly shift the bulk $\delta^{18} \mathrm{O}$ of subducted rocks. Microscale studies have the additional capacity to look at stages of hydration and incipient fluid alteration that are preserved in distinct mineral zones (Martin et al. 2014; Page et al. 2014), and distinguish between subduction and exhumation stages or even pre-subduction alteration at the ocean floor. They also shed light on the open question of whether fluids can circulate at a regional scale through interstitial percolation or if they move along discontinuities and fluid channels.

We apply a microanalytical approach (mineral composition, oxygen isotopes and age) to target distinct mineral zones that record individual stages of metamorphism and metasomatism in the well-studied sequence of the Monviso ophiolite. This exhumed oceanic sequence underwent subduction to $\sim 2.7 \mathrm{GPa}$ and has attracted attention for the well-preserved stratigraphy and variety of rock types involved (Lombardo et al. 1978; Angiboust et al. 2011) and for the evidence of fluid circulation at both the local and regional scale (Nadeau et al. 1993; Philippot 1993; Rubatto and Hermann 2003; Spandler et al. 2011; Angiboust et al. 2014). Therefore, we target a vein formed by local fluid circulation at high pressure as well as mylonitic eclogites within a large-scale shear zone. Importantly, we aim to reconstruct the $\mathrm{P}-\mathrm{T}$-time-fluids path for this sequence by targeting multiple minerals. Zircon has been investigated because it can provide time constraints on both protolith formation and Alpine metamorphism (Rubatto and Hermann 2003), but also because it is the only mineralogical relict of the oceanic stage. Garnet in these eclogites grows throughout the prograde and peak metamorphism and preserves spectacular zoning of this evolution (Angiboust et al. 2011). Antigorite is analysed for oxygen isotopes to investigate whether serpentinites are the source of fluids during high-pressure metamorphism (Spandler et al. 2011; Angiboust et al. 2014).

\section{Geological background}

The Monviso Lago Superiore Unit, located in the Western Alps (Italy), constitutes an exhumed 15-km long, continuous section of the Tethyan slow-spreading ocean seafloor that reached the lawsonite-eclogite facies field during Alpine subduction ( $\sim 80 \mathrm{~km}$ depth, Groppo and Castelli 2010) around $45 \mathrm{Ma}$ ago (Rubatto and Hermann 2003). The Lago Superiore Unit is crosscut by two major, kmscale eclogite-facies shear zones, respectively, localized at the boundary between metabasalts and metagabbros (ISZ: intermediate shear zone) and between metagabbros and underlying serpentinites (LSZ: lower shear zone; Fig. 1a). The top of the thick $\mathrm{Mg}-\mathrm{Al}$ metagabbro body is capped by a 20-30-m-thick layer of fine-grained mylonitic Fe-Ti metagabbros hosting eclogite-facies crack-seal veins (Philippot 1993) which yielded a U-Pb zircon age of $45 \pm 1 \mathrm{Ma}$ (Rubatto and Hermann 2003). Identical mylonitized Fe-Ti metagabbro fragments are also found in the LSZ, embedded as centimetre-sized to $15-\mathrm{m}$ rounded blocks wrapped by talcschists, chloriteschists and serpentinites (Fig. 1b; Angiboust et al. 2011). LSZ tectonic blocks can be followed continuously for more than $10 \mathrm{~km}$ along-strike, highlighting the regional importance of the LSZ as a 

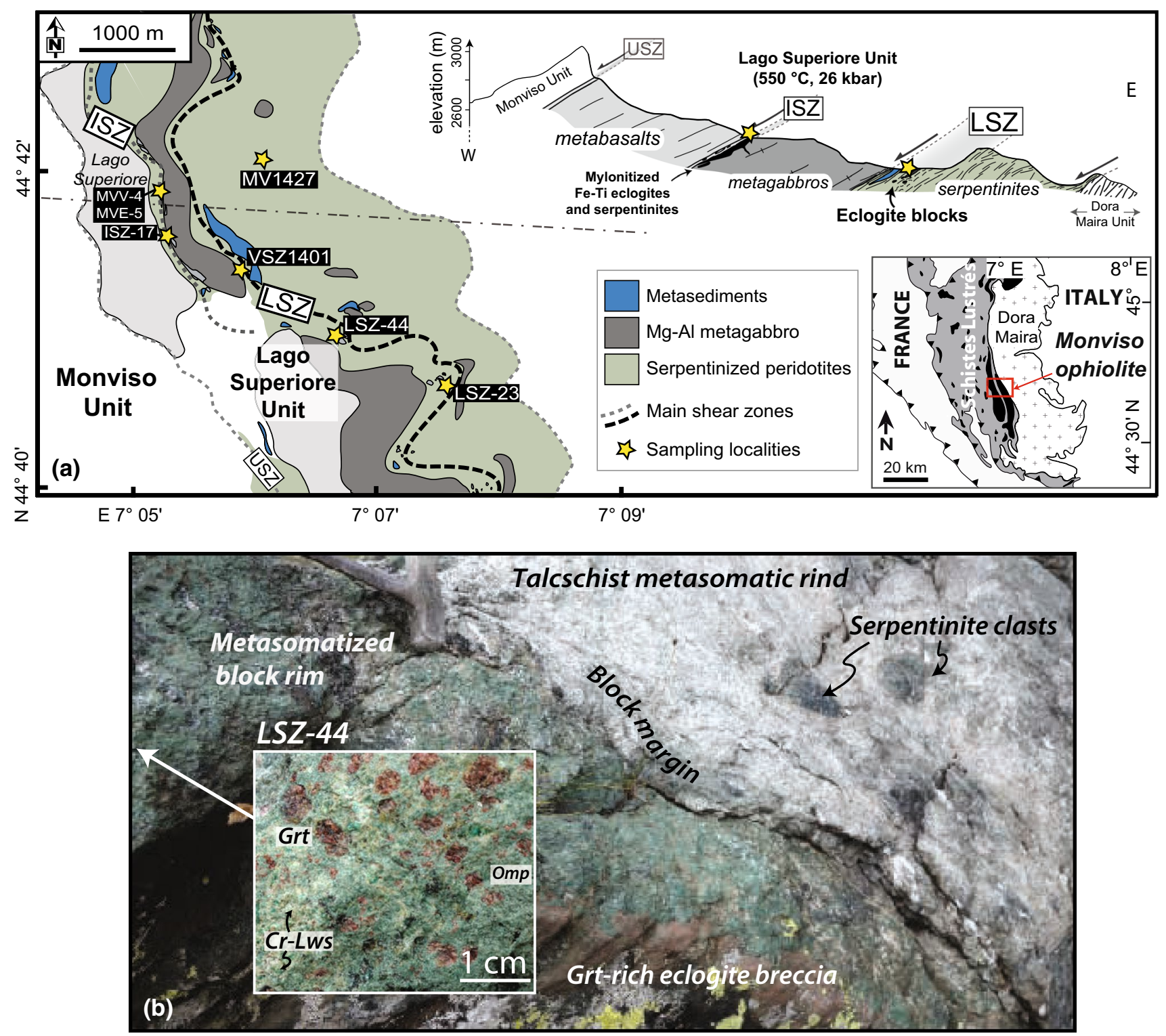

Fig. 1 a Geological map and cross section of the Monviso ophiolite showing the structure of the Lago Superiore unit and the location of studied eclogite-facies shear zones and investigated samples. The inset shows the location of the Monviso ophiolite in the Western Alps, along the French-Italian border. b Outcrop view of the contact between a metasomatized block from the LSZ (locality LSZ44)

major tectonic feature at the massif scale. Some of these blocks exhibit eclogite-facies breccia textures, interpreted as relicts of an ancient fault zone (Angiboust et al. 2012a). Most of these blocks, including eclogite breccias, exhibit a strongly heterogeneous metasomatic overprint as testified by the formation of chlorite, lawsonite, phengite and talcbearing eclogites. Typical Lago Superiore textures, showing eclogite-facies veins cutting through a fine-grained and the surrounding ultramafic material (mainly serpentinite and talcschists). The inset shows a close-up view of a remarkably wellpreserved metasomatized eclogite containing pseudomorphs after $\mathrm{Cr}$ rich lawsonite. The block core exhibits an eclogite-breccia structure and contains decimetre-sized clasts of mylonitized Fe-Ti metagabbros (see description in Angiboust et al. 2012a)

mylonitic foliation (Philippot 1993; Rubatto and Hermann 2003), have been also observed within LSZ block cores. Partial metasomatic overprinting of ISZ samples by metamorphic fluids indicates that veining along the ISZ took place before metasomatic replacement. Constraining the age of this metasomatic overprint is therefore critical to evaluate the duration of deformation and fluid-rock processes in this deep subduction environment. 
Table 1 Summary of sample assemblage and results

\begin{tabular}{|c|c|c|c|c|c|c|}
\hline Sample & Rock type & $\begin{array}{l}\text { Location and refer- } \\
\text { ence }^{a}\end{array}$ & $\begin{array}{l}\text { Eclogitic paragen- } \\
\text { esis }\end{array}$ & Zircon age & Zircon oxygen & $\begin{array}{l}\text { Garnet and Antigor- } \\
\text { ite oxygen }\end{array}$ \\
\hline ISZ17 & $\begin{array}{l}\text { Mylonitic } \mathrm{Fe}-\mathrm{Ti} \\
\text { metagabbro }\end{array}$ & $\begin{array}{l}\text { ISZ } \\
\text { A et al. (2011, } \\
\text { 2012) }\end{array}$ & $\begin{array}{l}\text { Omp, Grt, Rt, Qz, } \\
\text { Gln, Phg, (Lws), } \\
\text { Py, Zrn }\end{array}$ & - & - & $\begin{array}{l}\text { Grt: Cores } 2.6-3.8 \% o \\
\text { Rims } 2.0-3.2 \% 0\end{array}$ \\
\hline MVE5 & Fe-Ti metagabbro & $\begin{array}{l}\text { ISZ } \\
\text { R\&H (2003) }\end{array}$ & $\begin{array}{l}\text { Omp, Grt, Rt, Qz, } \\
\text { Gln, Phg, Py, Zrn }\end{array}$ & $\begin{array}{l}\text { Cores } 163 \pm 2 \mathrm{Ma} \\
\text { (1) }\end{array}$ & $\begin{array}{l}\text { Cores } 4.3-6.1 \% o \\
\text { Altered cores } \\
2.9-4.5 \% 0\end{array}$ & Grt: $2.3-3.1 \%$ \\
\hline MVV4 & $\begin{array}{l}\text { Vein crosscutting } \\
\text { MVE-5 }\end{array}$ & $\begin{array}{l}\text { ISZ } \\
\text { R\&H (2003) }\end{array}$ & $\begin{array}{l}\text { Omp, Grt, Tlc, Rt, } \\
\text { Zrn, Ap }\end{array}$ & $46 \pm 1 \mathrm{Ma}(1)$ & $1.6-3.6 \%$ & Grt: $2.0-3.0 \%$ \\
\hline LSZ44 & $\begin{array}{l}\text { Metasomatized } \mathrm{Fe}- \\
\text { Ti metagabbro }\end{array}$ & $\begin{array}{l}\text { LSZ } \\
\text { A et al. (2011, } \\
\text { 2014) }\end{array}$ & $\begin{array}{l}\text { Omp, Grt, Rt, } \\
\text { (Lws), Tlc, Py, } \\
\text { Ap, Zrn, }\end{array}$ & $\begin{array}{l}\text { Cores } 163-73 \mathrm{Ma} \\
\text { Rims } \\
\quad 45.8 \pm 0.7 \mathrm{Ma}\end{array}$ & $\begin{array}{l}\text { Cores } 4.6-5.7 \% o \\
\text { Rims } 1.9-3.8 \% \text { o }\end{array}$ & \\
\hline LSZ23 & $\begin{array}{l}\text { Metasomatized } \mathrm{Fe}- \\
\text { Ti metagabbro }\end{array}$ & $\begin{array}{l}\text { LSZ } \\
\text { A et al. (2011, } \\
\text { 2014) }\end{array}$ & $\begin{array}{l}\text { Omp, Grt, Mg-Chl, } \\
\text { Rt, Py }\end{array}$ & Yield no zircon & & $\begin{array}{l}\text { Grt: Cores } 0.2-2.0 \% o \\
\text { Rims 3.5-6.0\%o }\end{array}$ \\
\hline VSZ1401 & Serpentinite & LSZ & Atg, Mag, Chl & - & - & Atg: $2.95 \pm 0.25 \%$ \\
\hline MV1427 & Serpentinite & $\begin{array}{l}\text { Serpentinite unit } \\
\text { below LSZ }\end{array}$ & Atg, Mag, Chl & - & - & Atg: $3.6 \pm 0.2 \%$ \\
\hline
\end{tabular}

Lws, pseudomorphs after lawsonite that primarily consist of epidote and paragonite in variable proportions

a Sample previous described in Angiboust et al. (A et al.) (2011, 2012a, b, 2014) and Rubatto and Hermann (R\&H) (2003)

b Mineral abbreviations according to Whitney and Evans (2010)

\section{Sample descriptions}

All the samples investigated here were used in previous studies, and thus their description is kept brief. Full assemblages are given in Table 1. Most samples are eclogites that are derived from $\mathrm{Fe}-\mathrm{Ti}$ metagabbros (abundant rutile present) and which display different degrees of hydration and metasomatism. The samples are from two tectonic settings: the intermediate shear zone and the lower shear zone of Angiboust et al. (2011). Angiboust et al. (2011, 2014) concluded on the basis of petrological and geochemical evidence that the samples from the LSZ are the product of hydration and metasomatism of the $\mathrm{Fe}$-Ti metagabbro similar to those within the ISZ.

Eclogitic metagabbro MVE5 and crosscutting vein MVV4 were collected in the Lago Superiore Unit (Lombardo et al. 1978; Angiboust et al. 2011), south of the homonyms lake and within the ISZ. Both samples were previously investigated by Rubatto and Hermann (2003) for mineral trace element composition and zircon $\mathrm{U}-\mathrm{Pb}$ geochronology. Similar samples were also studied by Spandler et al. (2011) for trace elements. The eclogite preserves a fresh eclogitic assemblage (Omp and Grt with minor Qtz, Rt, Gln, Phg) and a foliated texture. The crosscutting vein is $40 \mathrm{~cm}$ thick and has a spectacular, coarse eclogitic assemblage (Omp, Grt with minor Tlc, Rt). Mylonitic eclogite ISZ-17 is similar in assemblage and location to sample MVE5, but has a stronger mylonitic foliation and also contains rare pseudomorphs after lawsonite (primarily aggregates of epidote and paragonite). The sample was previously described in Angiboust et al. (2011, 2012b, 2014).

Eclogites LSZ44 and LSZ23 are two typical lithologies encountered along the LSZ and were previously described by Angiboust et al. (2011, 2012b, 2014). LSZ44 is a mylonitic eclogite with abundant Cr-bearing pseudomorphs after lawsonite associated (Fig. 1b) with a typical eclogitic assemblage (Omp, Grt and minor Rt and Tlc). Accessory zircon and apatite are particularly abundant and large in size. Mass balance calculations have shown that sample LSZ44 contains on average 20 times more zirconium than the $\mathrm{Fe}-\mathrm{Ti}$ metagabbroic protolith it derives from, suggesting mobility of $\mathrm{Zr}$ and enrichment in metamorphic fluids during the metasomatic event (Rubatto and Hermann 2003; Angiboust et al. 2014). Sample LSZ23 is characterized by the presence of $\mathrm{Mg}$-chlorite ( $5 \%$ in volume) in equilibrium with garnet and omphacite.

Two serpentinites for oxygen isotope analysis were collected within the Lago Superiore Unit: sample VSZ1401 within the LSZ and sample MV1427 from the serpentinized peridotite unit below the LSZ. Both samples, representative of the bulk of Lago Superiore Unit serpentinite sole, contain antigorite, magnetite and minor amounts of chlorite.

\section{Methods}

Zircons were analysed as grain separates, whereas garnet and antigorite were analysed directly in thin section 
or polished rock chip. Zircon grains were separated after rock crushing using conventional heavy liquid and a Frantz magnetic separator. The grains were handpicked, mounted in epoxy resin together with the standard and polished down to expose the near equatorial section. Thin section cuts exposing garnet crystals and rock chips containing antigorite were also mounted in epoxy together with a polished standard block.

Cathodoluminescence (CL) and back-scattered electron (BSE) investigation for zircon and garnet, respectively, was carried out on a JEOL JSM-6610A scanning electron microscope (SEM) supplied with an ellipsoidal mirror for CL at the Research School of Earth Sciences (RSES), Australian National University. Operating conditions for the SEM were $15 \mathrm{kV}$, a load current of 65-75 $\mu \mathrm{A}$ and a 10-12$\mathrm{mm}$ working distance.

$\mathrm{U}-\mathrm{Pb}$ and oxygen isotope analyses were obtained with the sensitive high-resolution ion microprobes (SHRIMP II and SHRIMP SI) at the ANU in Canberra. Instrumental conditions and data acquisition for U-Pb (SHRIMP II instrument) were generally as described by Williams (1998). The data were collected in sets of six scans throughout the masses, and the TEM reference zircon (Temora granodiorite, Black et al. 2003) was analysed each fourth analysis. The fraction of non-radiogenic ${ }^{206} \mathrm{~Pb}\left(f_{206}\right)$ was calculated from the measured ${ }^{207} \mathrm{~Pb} /{ }^{206} \mathrm{~Pb}$ $\left({ }^{7 / 6} R_{\mathrm{m}}\right)$ and the non-radiogenic ${ }^{207} \mathrm{~Pb} /{ }^{206} \mathrm{~Pb}\left({ }^{7} R_{\mathrm{c}}\right)$ according to Williams (1998), i.e. $f_{206}=\left({ }^{7 / 6} R_{\mathrm{m}}-{ }^{7 / 6} R^{*}\right) /$ $\left({ }^{7 / 6} R_{\mathrm{c}}-{ }^{7 / 6} R^{*}\right)$, where ${ }^{7 / 6} R^{*}$ is the expected radiogenic ${ }^{207} \mathrm{~Pb} /{ }^{206} \mathrm{~Pb}$ assuming concordance at the approximate age of the sample. The ${ }^{7} R_{\mathrm{c}}$ composition was assumed to be that predicted by Stacey and Kramers (1975). The resulting $f_{206}$ varies between 0 and $14 \%$, mostly below $2.5 \%$, with the highest values for the Eocene domains. Data evaluation and age calculation were done using the software Squid 1 and Isoplot/Ex (Ludwig 2003), respectively. $\mathrm{U}-\mathrm{Pb}$ data were collected in analytical sessions with a calibration error of $1.7 \%$ ( 2 sigma), which was propagated to single analyses. Average ages are quoted at $95 \%$ confidence level (c.l.).

Oxygen isotope analyses of zircon (SHRIMP II and SHRIMP SI) followed the protocols detailed in Ickert et al. (2008) and used Temora zircon (Black et al. 2003) as reference material. For garnet, the analysis protocol is detailed in Martin et al. (2014) and UWG2 garnet $\left(\delta^{18} \mathrm{O}=5.8 \%\right.$, Valley et al. 1995) was the primary standard. An off-line matrix bias correction for the grossular and spessartine component of garnet was applied following the equation given in Martin et al. (2014). The resulting matrix bias correction for individual analyses is typically between 0.5 and $1 \%$. The garnet composition for each SHRIMP spot was based on EDS analyses with the JEOL JSM 6610-A scanning electron microscope.
Oxygen isotope analysis of serpentine (SHRIMP SI) followed a similar protocol to garnet and zircon with details reported in Scicchitano et al. (in preparation). Antigorite from a serpentinite from the Almirez high-pressure sequence (Padrón-Navarta et al. 2011) was used as a standard with a reference $\delta^{18} \mathrm{O}$ value of $8.30 \pm 0.06 \%$ (M. Scicchitano personal communication). Our data indicate that there is no significant orientation effect in ion microprobe analysis of antigorite, nor a matrix effect due to antigorite composition within the compositional range of natural serpentine.

Errors on individual oxygen analyses are typically 0.05 $0.1 \%, 1 \sigma$, but in the case of garnet the uncertainty from the matrix correction $( \pm 0.25 \%$ o, $1 \sigma$, Martin et al. 2014) is added in quadratic. Average values are presented for most samples and in the cases where data are scattered above analytical uncertainty, the uncertainty is given as standard deviation and not as standard error.

\section{Results}

\section{Zircon U-Pb geochronology}

For the lower shear zone, zircon crystals were separated from mylonitic eclogite LSZ44, which has a high Zr content of 1014 ppm (Angiboust et al. 2014). Zircons could not be recovered from sample LSZ23, nor a similar chlorite-bearing eclogite. Zircons from the samples MVE5 and MVV4 were previously dated by Rubatto and Hermann (2003) and are representative of the intermediate shear zone samples. That study demonstrated that Alpine zircon in sample MVV4 formed at eclogite-facies conditions according to inclusions of rutile and REE patterns with a typical eclogitic signature.

Zircon crystals in eclogite LSZ44 consist of core and rim that differ in CL zoning and age (Fig. 2). The zircon cores commonly preserve euhedral shape and have a weak oscillatory zoning with superimposed sectors or fir-tree zoning. Such cores are similar to magmatic zircons from sample MVE5 (Rubatto and Hermann 2003). U-Pb analyses of zircon cores returned scattered dates between 164 and $73 \mathrm{Ma}$ with no significant age cluster (Online Resource Table 1). However, it is significant that the oldest dates measured coincide with the age of the magmatic cores in eclogite MVE5 (163 \pm 2 Ma, Rubatto and Hermann 2003). Some of the dates have relatively large errors as the analysed cores are low in $\mathrm{U}$ (down to $1-59 \mathrm{ppm}$ ) and thus radiogenic $\mathrm{Pb}$. Th/ $\mathrm{U}$ of $0.2-0.5$ is typical of magmatic zircons.

Thin rims (a few to $30 \mu \mathrm{m}$ thick) are present on most zircon cores and have dark CL that shows no or faint zoning. Rims can also be euhedral in shape. The rims are only marginally richer in $U$ (10-132 ppm) than the cores and very 
Fig. 2 LSZ44 eclogite zircon geochronology. Tera-Wasserburg plot (left) for uncorrected $\mathrm{U}-\mathrm{Pb}$ analyses of zircon rims. Ellipses represent 2 sigma uncertainties. CL images of representative zircon crystals (right) with indicated the location of the SHRIMP analysis (circle) and corresponding age in $\mathrm{Ma} \pm 1$ sigma uncertainty
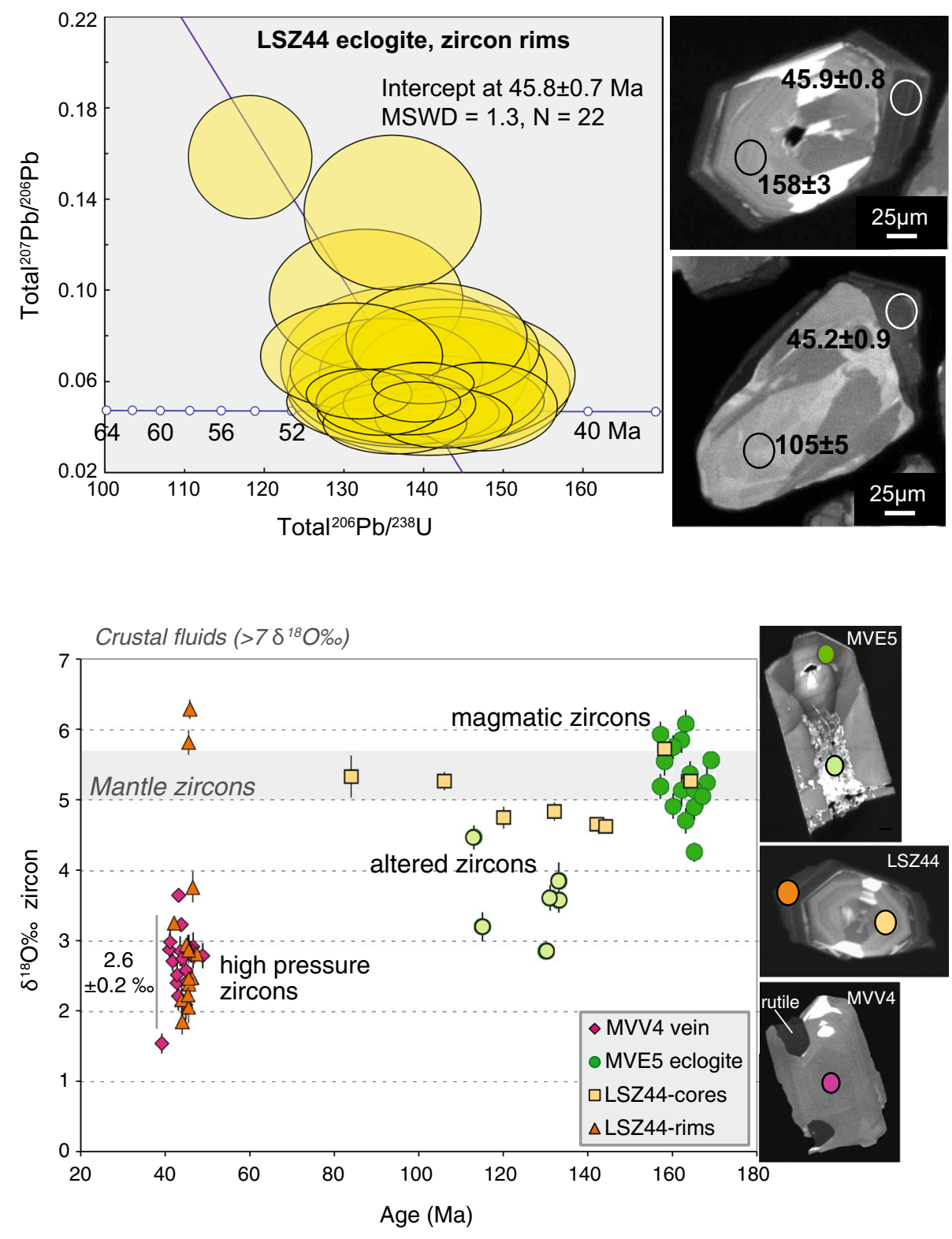

Fig. 3 Zircon $\delta^{18} \mathrm{O}$ values versus age for the different samples. The grey band represents the average $\delta^{18} \mathrm{O}$ value for mantle zircons $(5.3 \pm 0.3 \%$, Valley 2003). Error bars represent \pm 2 sigma, and they can be smaller than the symbols. The CL images on the right of the diagram show representative zircon grains for each sample with spot size location (spot size $\sim 25 \mu \mathrm{m}$ across). Note that in sample MVE5 the domains with disturbed $\mathrm{CL}$ domains ("altered") returned lower $\delta^{18} \mathrm{O}$ values than the pristine magmatic domains poor in Th $(0.1-4 \mathrm{ppm})$ with $\mathrm{Th} / \mathrm{U}$ in the range $0.005-0.1$. $\mathrm{U}-\mathrm{Pb}$ analyses define an intercept age of $45.8 \pm 0.7 \mathrm{Ma}$ (MSWD $=1.3, N=22$ ) with the exclusion of one apparently younger rim.

\section{Zircon oxygen isotopes}

The oxygen isotope composition of zircons was analysed for two samples from the intermediate shear zone (metagabbro MVE5 and vein MVV4) and one sample from the lower shear zone (eclogite LSZ44). Magmatic zircon cores from both localities have $\delta^{18} \mathrm{O}$ values mostly between 4.5 and $6 \%$ (Fig. 3; Online Resource Table 2). Zircon cores in eclogite MVE5, which show signs of alteration in their CL zoning and yield younger ages $(\sim 135$ to $110 \mathrm{Ma})$, systematically returned lower $\delta^{18} \mathrm{O}$ values of 2.9-4.5\%o with respect to the pristine magmatic cores. Zircon cores with oscillatory/sector zoning in eclogite LSZ44 yield $\delta^{18} \mathrm{O}$ values around $5 \%$, even though the ages of these domains have a significant scatter from 164 to $84 \mathrm{Ma}$.

Zircon domains that yield Alpine ages, both in eclogitic vein MVV4 and in eclogite LSZ44, have, with a few exceptions, distinctly lower $\delta^{18} \mathrm{O}$ values from 1.6 to $3.8 \%$. Most analyses form a cluster with an overall average value of $2.6 \pm 0.2 \%$ (SE at $95 \%$ c.l., $N=27$ ). Two Alpine rims from sample LSZ44 yield higher $\delta^{18} \mathrm{O}$ values around $6 \%$ that are similar to the core values. 


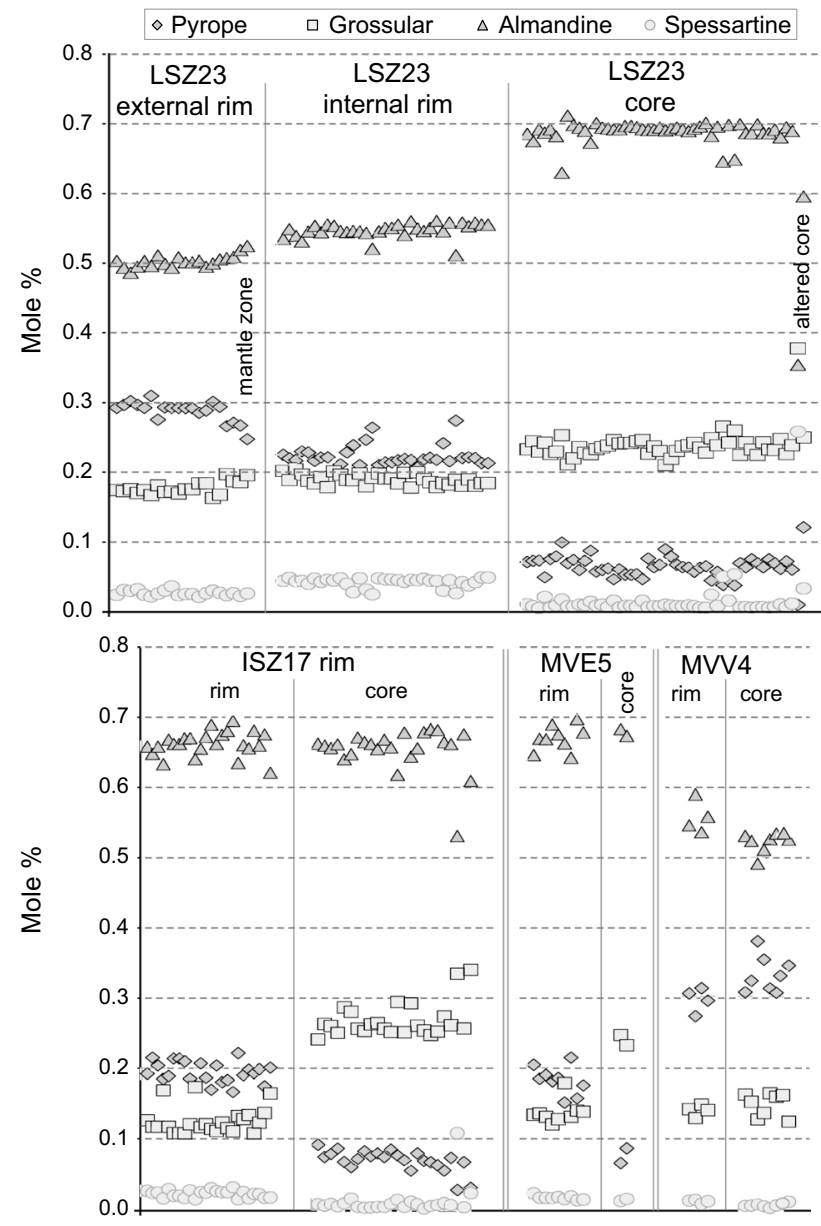

Fig. 4 Garnet composition for different samples and domains (corerim) expressed in mole per cent of almandine, pyrope, grossular and spessartine. Data for each sample are a summary of analyses from different garnet grains and thus are not plotted according to distance from rim. Note that in most samples core and rim are relatively homogeneous when compared to core-rim variations

\section{Garnet oxygen isotopes}

Garnet was analysed for oxygen isotopes in four samples (Figs. 4, 5, 6, 7; Online Resource Figs. 1-3 and Tables 3, $4,5)$ from the intermediate shear zone eclogites (ISZ17, MVE5), a metamorphic vein (MVV4) and the lower shear zone eclogite (LSZ23). The samples include rock types that were affected by local fluid circulation as proposed by Philippot (1993) and Rubatto and Hermann (2003) (MVE5 and MVV4), and the large-scale structures and fluid channels investigated by Angiboust et al. (2011, 2012b, 2014), here represented by sample ISZ17 and LSZ23. Rutile is a common inclusion in the investigated garnet grains from all samples.

Garnet in eclogite MVE5 shows limited zoning (Fig. 4) with patchy core areas richer in $\mathrm{Ca}$ and poorer in $\mathrm{Mg}\left(\operatorname{Prp}_{6-9}\right.$, $\mathrm{Grs}_{23-25}, \mathrm{Sps}_{1.2-1.5}, \mathrm{Alm}_{67-68}$ in mole \%) with respect to the rims $\left(\operatorname{Prp}_{15-20}, \mathrm{Grs}_{12-14}, \mathrm{Sps}_{1.3-2.3}, \mathrm{Alm}_{64-69}\right)$. The oxygen composition is similar in both domains with $\delta^{18} \mathrm{O}$ values between 2.3 and $3.1 \%$ (average $2.8 \pm 0.2 \%$, SE at $95 \%$ c.l., $N=11$; Fig. $5 \mathrm{a}$, e). Garnet from vein sample MVV4 has much higher $\mathrm{Mg}$ contents $\left(\operatorname{Prp}_{27-38}, \mathrm{Grs}_{12-16}, \mathrm{Sps}_{0.5-1.4}\right.$, $\left.\mathrm{Alm}_{49-59}\right)$ than garnet in the nearby eclogites. BSE images (see also Online Resource Fig. 1) reveal a thin $(<100 \mu \mathrm{m}$ across) bright zone along the grain margin and fractures, which corresponds to a slightly higher $\mathrm{Mg}$ and $\mathrm{Mn}$ content $\left(\mathrm{Sps}_{0.8-1.4}\right)$ and possibly increased $\mathrm{Y}+\mathrm{REE}$. Despite the different chemical composition, the $\delta^{18} \mathrm{O}$ of garnet in MVV4 is similar to that of the surrounding eclogite with values of 2.0-3.0\% (average $2.4 \pm 0.2 \%$ o, SE at $95 \%$ c.l., $N=12$ ) with no significant difference between the Mn-rich rims and the rest of the crystal (Figs. 5e, 7).

Garnet in eclogite ISZ17 is zoned (Figs. 4, 5, 7; Online Resource Fig. 2) with partly resorbed cores that are poorer in $\mathrm{Mg}$ and $\mathrm{Mn}$ and richer in $\mathrm{Ca}\left(\operatorname{Prp}_{3-9}, \mathrm{Grs}_{24-34}, \mathrm{Sps}_{0.2-1.0}\right.$, $\left.\mathrm{Alm}_{61-68}\right)$ than the rims $\left(\operatorname{Prp}_{17-22}, \mathrm{Grs}_{11-16}, \mathrm{Sps}_{1.4-3.0}\right.$, $\mathrm{Alm}_{62-68}$ ), with equal almandine component (see also Angiboust et al. 2011). Chemical zoning between garnet core and rim correspond to a small difference in isotopic composition: cores $=2.6-3.8 \%$ (one analysis yielded $4.3 \%$ ) and rims $=2.0-3.2 \%$ (Fig. 5f). When the average rim and core $\delta^{18} \mathrm{O}$ values are considered for single grains, the core-rim difference varies between 0 and $1 \%$ (Fig. $5 \mathrm{~g}$ ). The overall average for garnet core analyses is $3.3 \pm 0.8 \%$, $2 \mathrm{SD}$, $N=24$, whereas the rims are $2.8 \pm 0.6 \%$ o, $2 \mathrm{SD}, N=24$. The core and rim $\delta^{18} \mathrm{O}$ values overlap with the oxygen composition of garnet in eclogite MVE5 and vein MVV4.

The eclogite sample from the lower shear zone (LSZ23) has a different garnet composition in both major elements and oxygen isotopes (Figs. 4, 6, 7). Garnet grains are spectacularly zoned as already reported in Angiboust et al. (2011, 2014). Three main zones can be distinguished (Figs. 4, 6a-d): BSE-bright cores that are $\mathrm{Mg}$ and $\mathrm{Mn}$ poor, Fe and $\mathrm{Ca}$ rich $\left(\mathrm{Prp}_{5-10}, \mathrm{Grs}_{21-26}, \mathrm{Sps}_{0.5-2.4}, \mathrm{Alm}_{65-71}\right),(2)$ an inner rim with increased $\mathrm{Mg}$ and $\mathrm{Mn}\left(\operatorname{Prp}_{20-27}, \mathrm{Grs}_{18-20}\right.$, $\mathrm{Sps}_{3-5}, \mathrm{Alm}_{51-56}$ ) and (3) an outer rim that is particularly BSE-dark and is compositionally close to the inner rim, but slightly lower in $\mathrm{Mg}, \mathrm{Fe}$ and $\mathrm{Mn}\left(\operatorname{Prp}_{25-31}, \mathrm{Grs}_{17-20}\right.$, $\left.\mathrm{Sps}_{2.4-3.3}, \mathrm{Alm}_{49-50}\right)$. The boundary between the core and the inner rim is at times gradual with a $20-30-\mu \mathrm{m}$ irregular mantle zone. The garnet core is crossed by a network of alteration zones, commonly along fractures and inclusions. This altered core has a quite variable composition with high spessartine content between 7 and 26 mole \% $\left(\operatorname{Prp}_{10}, \mathrm{Grs}_{25-38}, \mathrm{Sps}_{7-26}, \mathrm{Alm}_{35-60}\right.$; Fig. 4). While the LSZ23 BSE-bright garnet cores are compositionally close to ISZ17 garnet core, their oxygen isotopic composition is markedly different from the other samples (Fig. 7). LSZ23 cores have very low $\delta^{18} \mathrm{O}$ values $(0.2-2.0 \%$, average $1.4 \pm 1.2 \%$, $2 \mathrm{SD}, N=47$ ). Rims have an heavier 

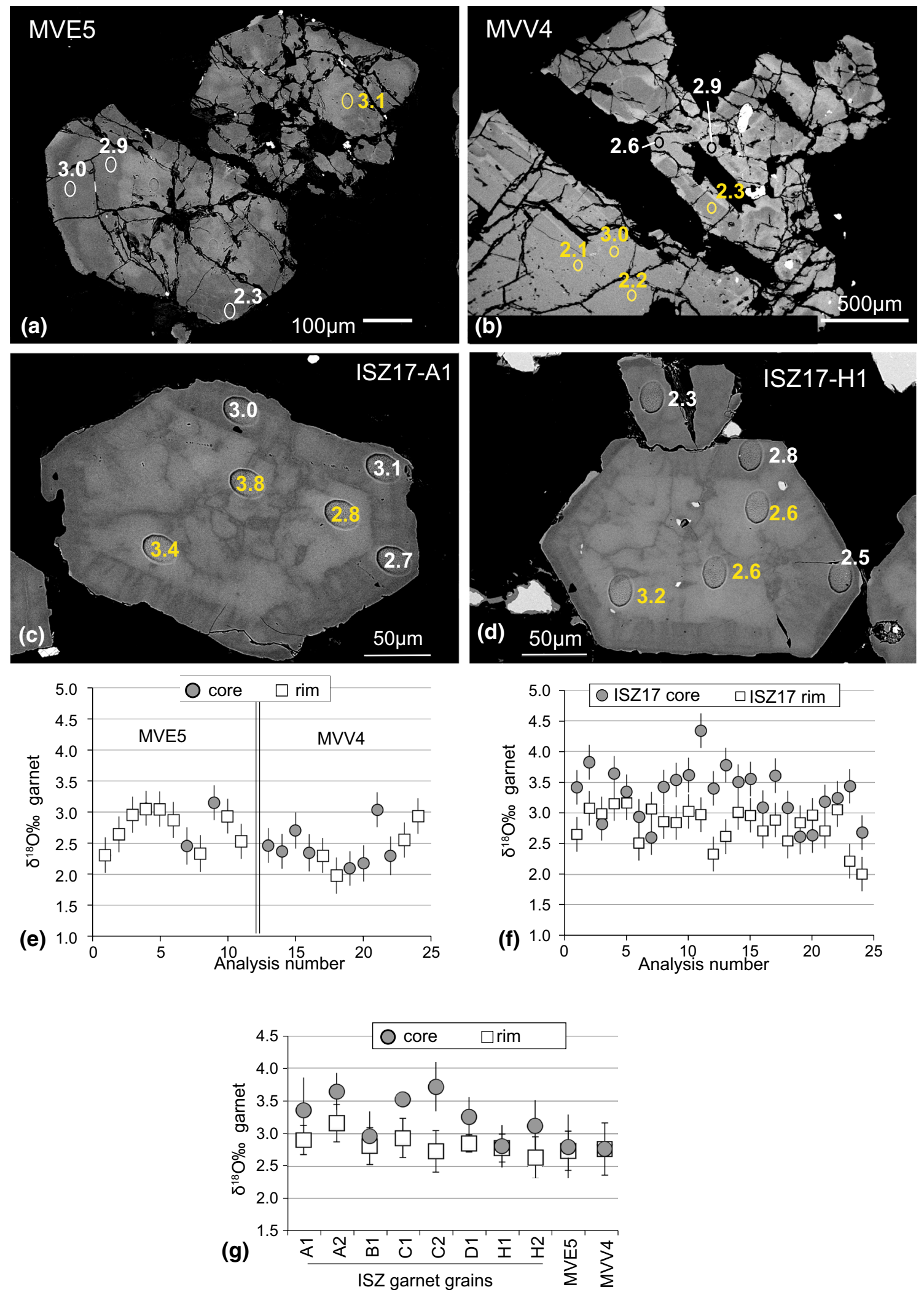

Fig. 5 a-d BSE images of representative garnet grains from samples from the intermediate shear zone MVVE, MVV4 and ISZ17 (grain A1 and H1 shown). The location of the SHRIMP analysis (circle or visible pits) and corresponding $\delta^{18} \mathrm{O}$ value in $\%$ are reported. e, $\mathbf{f}$ $\delta^{18} \mathrm{O}$ results for garnet from sample MVV4 and MVE5 (e) and ISZ17 (f) divided by domain. $\mathbf{g}$ Average core and $\operatorname{rim} \delta^{18} \mathrm{O}$ for the different garnet crystals (A1, A2 ..H2) in sample ISZ17 and for all analyses of garnet MVE4 and MVV4. Error bars in plot $\mathbf{e}-\mathbf{g}$ represent \pm 1 sigma 

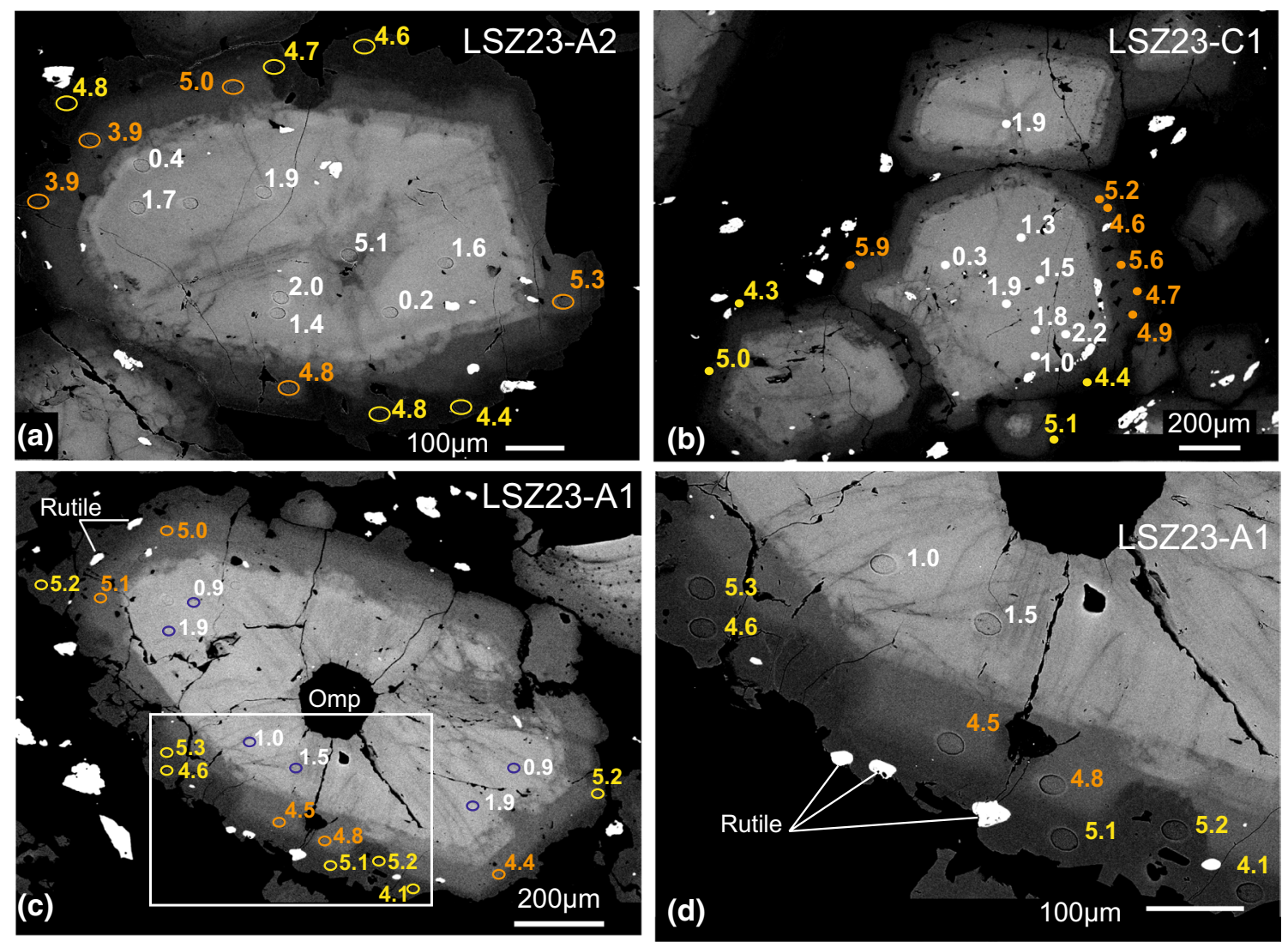

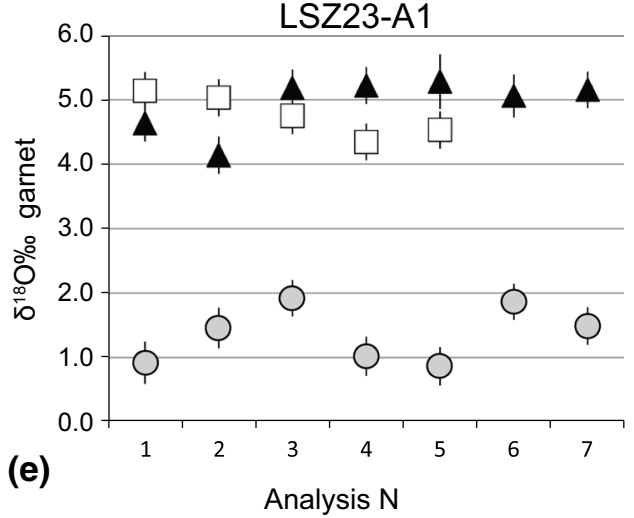

Fig. 6 a-d BSE images of representative garnet grains from sample LSZ23. Three main garnet zones are visible: bright core, internal rim and dark external rim. The location of the SHRIMP analysis (circle or visible pits) and corresponding $\delta^{18} \mathrm{O}$ value in $\%$ are reported. The bright inclusions are rutile, and the dark inclusions are omphacite

oxygen isotope composition that is only partly overlapping with the other samples $\left(\delta^{18} \mathrm{O}\right.$ of 3.5-6.0 \%o, average $4.7 \pm 1.0 \%$, $2 \mathrm{SD}, N=53$ ) and with little or no difference between inner and outer rims. Although there is some scatter in the data within single garnet crystals (see an example in Fig. 6e), the average core and rim $\delta^{18} \mathrm{O}$ compositions in each LSZ23 garnet crystal differ by 3.3-3.7\%o (Fig. 6f).

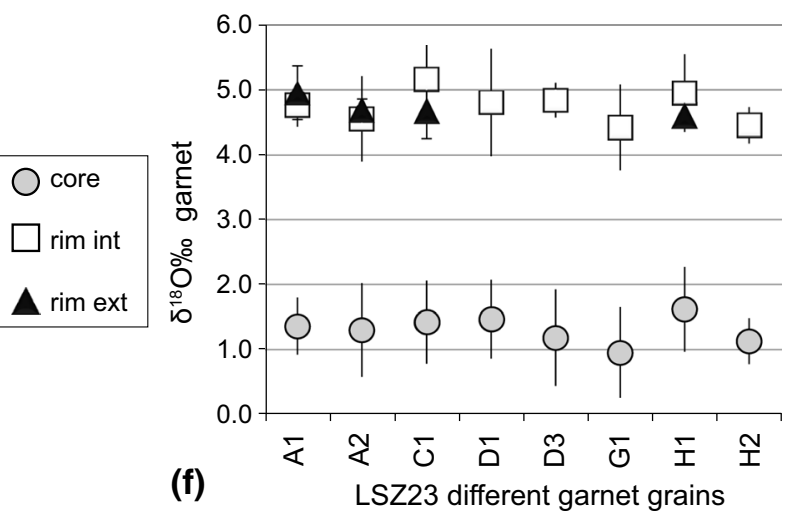

(Omp). e $\delta^{18} \mathrm{O}$ results for garnet crystal LSZ23-A1 (shown in BSE image $\mathbf{c}$ and d) divided by domain. See Fig. 7 for all LSZ23 analyses. f Average core and $\operatorname{rim} \delta^{18} \mathrm{O}$ composition for different garnet crystals (A1-H2) in sample LSZ23. Error bars in plot $\mathbf{e}$ and $\mathbf{f}$ represent \pm 1 sigma

\section{Serpentine oxygen isotopes}

Antigorite was analysed from a mylonitic serpentinite within the LSZ (VSZ1401) and a serpentinite from the unit below the LSZ (MV1427). The sample contains antigorite intimately associated with fine-grained magnetite. Oxygen analyses across different crystals of antigorite returned identical results within sample, with some additional 
Fig. 7 Garnet $\delta^{18} \mathrm{O}$ results plotted against garnet composition expressed in mole \% of a pyrope, $\mathbf{b}$ almandine, $\mathbf{c}$ grossular and $\mathbf{d}$ spessartine. Grey arrows in a indicate the shift from garnet core to rim in samples ISZ17 and LSZ23. Uncertainties on single analyses are not plotted for clarity and are typically $\pm 0.3 \%$ o, 2 sigma, including the error from the matrix correction

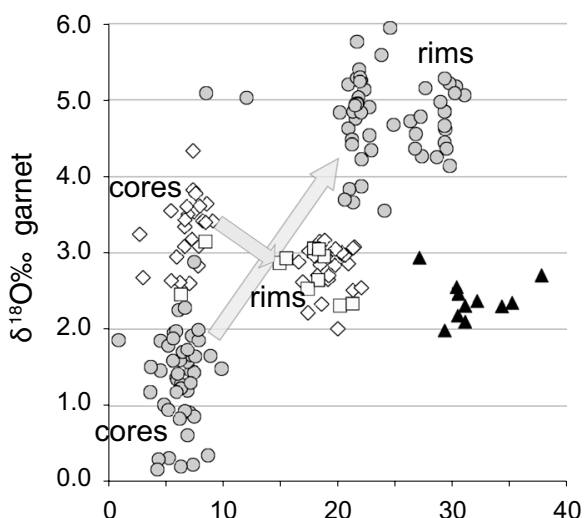

(a)

Pyrope (mole \%)

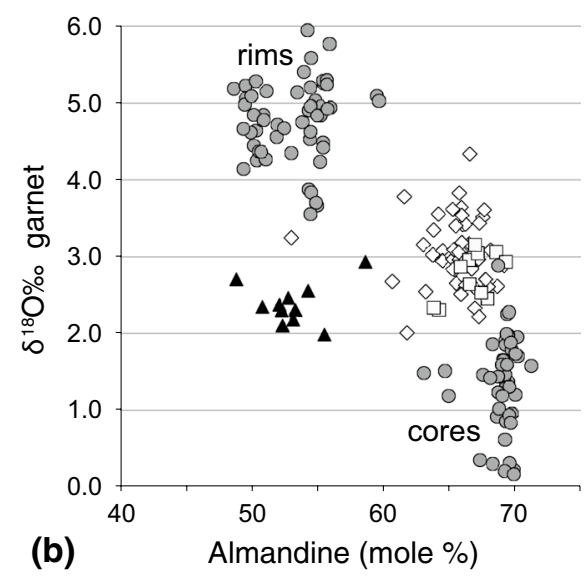

$\diamond$ ISZ17 $\square$ MVE5 \MVV4 oLSZ23

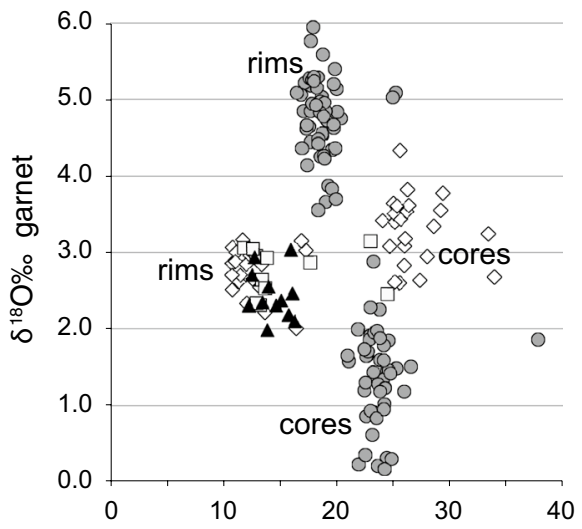

(c) Grossular (mole \%)

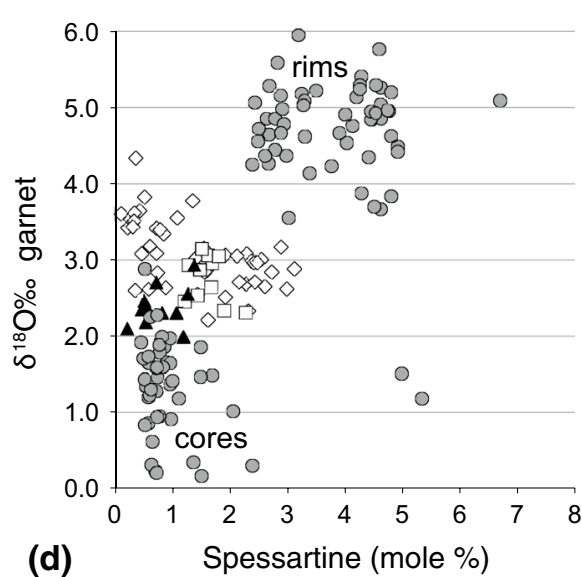

(d)

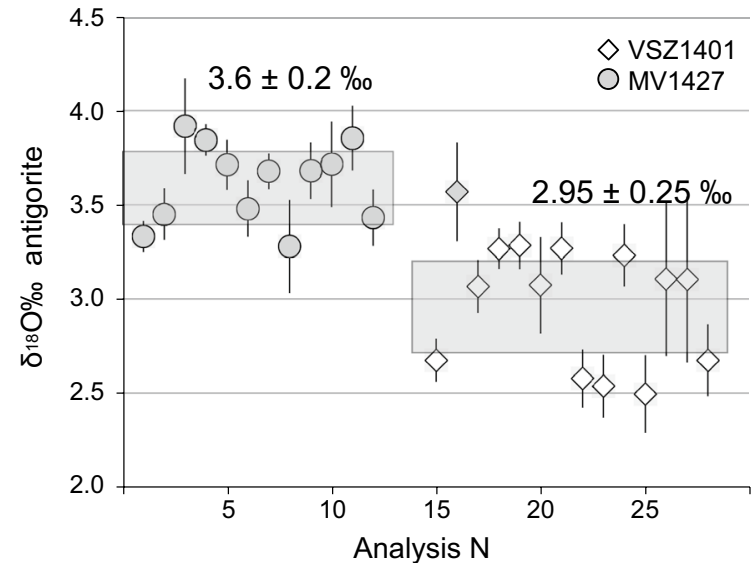

Fig. 8 Antigorite $\delta^{18} \mathrm{O}$ results for the two serpentinite samples. Error bars on single data points represent \pm 2 sigma. Averages are given at $95 \%$ confidence limit, and uncertainties include internal and external errors. One analysis (grey diamond) for sample VSZ1401 was

scatter in serpentinite VSZ1401. The average $\delta^{18} \mathrm{O}$ values in the two samples, with the exclusion of one analysis for VSZ1401, are $2.95 \pm 0.25$ and $3.6 \pm 0.2 \%$ o, respectively (Fig. 8).

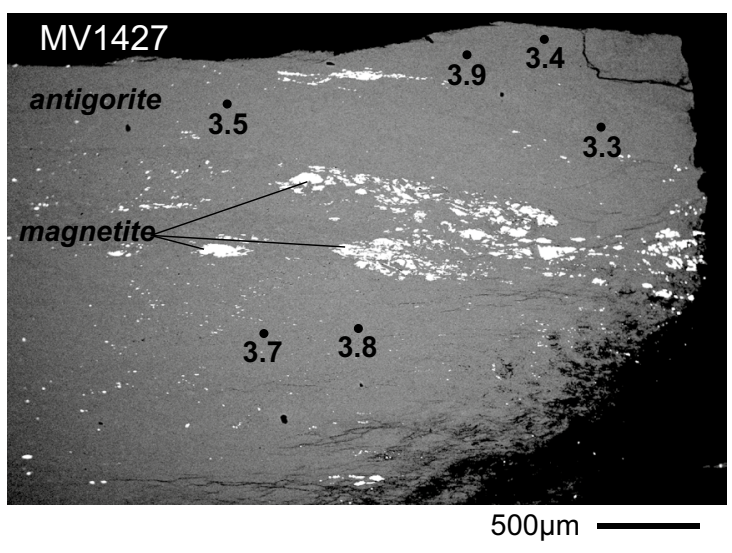

excluded from the average $\delta^{18} \mathrm{O}$ calculation. The BSE image on the right shows a typical analysis site; note that the intimate association of antigorite and magnetite can be resolved with in situ analysis

\section{Oxygen isotopic variations and P-T-time evolution}

In order to reconstruct a detailed P-T-time-fluids history for the Monviso Lago Superiore Unit (Fig. 9), it is 


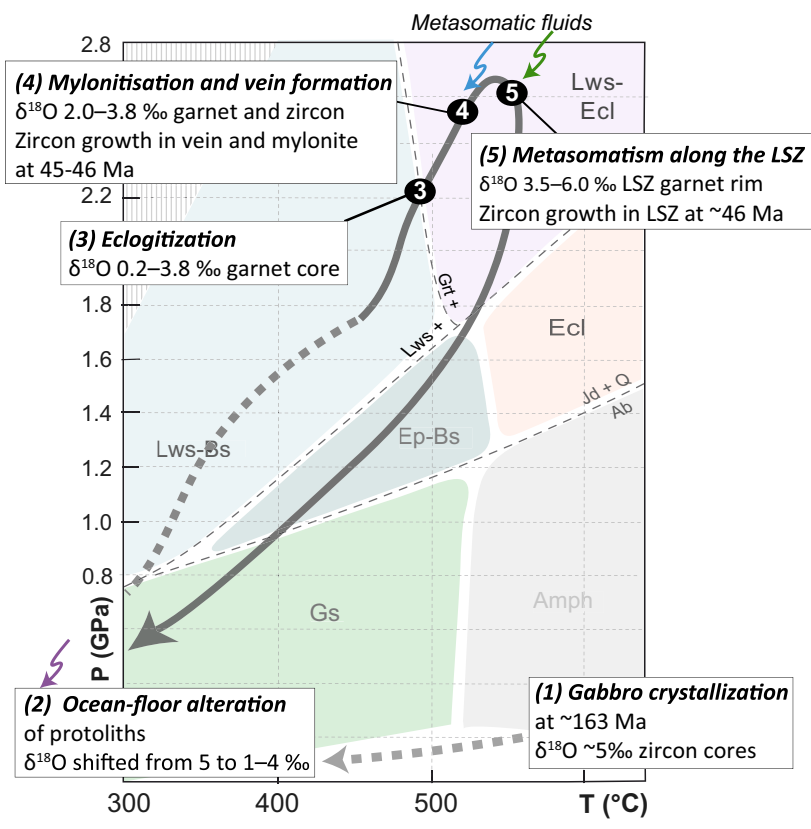

Fig. 9 Proposed P-T-time-fluid path for the Monviso Lago Superiore Unit. The PT path is from Angiboust et al. (2012b) and Groppo and Castelli (2010). Stages (1) and (2) refer to the oceanic evolution, and PT conditions are not precisely reported here. See text for details

necessary to combine the age obtained from zircon, the $\delta^{18} \mathrm{O}$ signatures for the different zircon and garnet zones and the P-T determinations previously published for these and other samples from Monviso Lago Superiore Unit. The history of the Lago Superiore unit is particularly well recorded in the oxygen isotope zoning of the investigated minerals. In reconstructing the history of the unit, we must consider that any variation in mineral $\delta^{18} \mathrm{O}$ can be due to three major causes: (1) variation in temperature of equilibration between minerals (from the $\sim 1200{ }^{\circ} \mathrm{C}$ of the gabbroic magma to the $550{ }^{\circ} \mathrm{C}$ of the eclogite); (2) changes in mineral assemblage and mineral mode during metamorphism (from protolith gabbro to eclogite); and/or (3) interaction with external fluids.

The combination of the petrological and isotopic data allows us to distinguish two major stages of metasomatism: a shallow oceanic stage and a high-pressure subduction stage.

\section{Protolith}

In these samples, magmatic zircon is the only mineral relict from the protolith gabbro. Such zircon relicts are present in sample MVE5 and LSZ44 from the intermediate and lower shear zone, respectively. The age of the most pristine zircon core is identical in the two samples: precisely dated at $163 \pm 2 \mathrm{Ma}$ in eclogite MVE5 (Rubatto and Hermann 2003) and up to $163 \mathrm{Ma}$ in a few zircon cores in mylonitic eclogite LSZ44. The scatter in zircon core ages in sample LSZ44 is likely due to disturbance of the $\mathrm{U}-\mathrm{Pb}$ system during Alpine mylonitization and high-pressure metamorphism/metasomatism. This later overprint is also reflected in the modified oxygen isotope compositions of the altered zircon cores (Fig. 3). Jurassic ages are common for ophiolitic gabbros in the Western Alps (Manatschal and Müntener 2009). The $\delta^{18} \mathrm{O}$ of the Jurassic zircons in the Monviso samples is 4.5-6.0\%o, within the expected compositional range for zircons in equilibrium with the mantle $(5.3 \pm 0.3 \%$, Valley et al. 1998) and in line with gabbro protoliths within an ophiolitic sequence.

\section{Oceanic metasomatism}

Ocean floor metasomatism on the protolith of the eclogites can be inferred from the composition of the metamorphic minerals, which inevitably inherited the oceanic oxygen isotope composition. The Alpine zircon in vein MVV4 or rims in LSZ44 have a markedly different oxygen isotopic composition than the Jurassic zircon cores. Metamorphism of an oceanic gabbro in a closed system could not possibly shift the zircon oxygen isotopes of $-2.5 \%$. This can be demonstrated with a simple model. The approximate mineral modes of the gabbro protolith can be back calculated from the bulk-rock composition of sample MVE5 given in Rubatto and Hermann (50\% anorthite, $41 \%$ diopside, $9 \%$ ilmenite, $0.1 \%$ zircon); the temperature is assumed to be $1200{ }^{\circ} \mathrm{C}$ for gabbro crystallization. From an average zircon value of $5.3 \%$, the corresponding bulk $\delta^{18} \mathrm{O}$ is $5.7 \%$. If the $\delta^{18} \mathrm{O}$ bulk rock is kept constant (i.e. no external fluid influx) and the observed major metamorphic assemblage at $550{ }^{\circ} \mathrm{C}$ is taken $(50 \%$ garnet, $35 \%$ omphacite, $10 \%$ quartz and $5 \%$ rutile), the $\delta^{18} \mathrm{O}$ of the metamorphic minerals can be calculated. In the modelled eclogite, garnet would have a $\delta^{18} \mathrm{O}$ of $5.1 \%$ and metamorphic zircon $5.2 \%$, as the major phases diopside, omphacite and garnet do not fractionate oxygen in a significant way (oxygen fractionation factors from Zheng 1991, 1993b). In the modelling, diopside is used for omphacite as no specific oxygen fractionation factors exist for Na-pyroxene. In other words, the transition from a plagioclase + diopside (modelled $\delta^{18} \mathrm{O}$ of 5.9 and $5.5 \%$, respectively) dominated assemblage to a garnet + omphacite assemblage would shift the $\delta^{18} \mathrm{O}$ of the major metamorphic minerals to slightly lighter oxygen, which is compensated by quartz that has a heavier oxygen composition than most $\mathrm{Fe}-\mathrm{Mg}$ silicates. Importantly, no significant variation in $\delta^{18} \mathrm{O}$ between magmatic and metamorphic zircon would occur during metamorphism in a closed system. The coexisting metamorphic garnet would have $\delta^{18} \mathrm{O}$ values between 4.5 and $6 \%$, allowing for some variation due to growth temperature and mineral modal abundances. 
Therefore the changes in oxygen isotopes of $-2.5 \%$ observed from magmatic to metamorphic zircons (Fig. 3) must be due to metasomatism from external fluids. Such metasomatism could have occurred either during oceanic alteration, as documented in other Alpine ophiolites (Miller and Cartwright 2000), or during Alpine metamorphism, as argued by previous studies (Angiboust et al. 2011; Spandler et al. 2011; Angiboust et al. 2014). This shift in $\delta^{18} \mathrm{O}$ and the timing of metasomatism are best understood if the garnet data are considered.

Previous thermodynamic modelling of a NCKFMASHTO system, which best represents the Lago Superiore unit eclogites, indicates that garnet starts to form during prograde metamorphism at $T \sim 500{ }^{\circ} \mathrm{C}$ and $2.2 \mathrm{GPa}$, slightly below peak subduction at $\sim 550{ }^{\circ} \mathrm{C}$ and $2.4-2.7$ GPa (Groppo and Castelli 2010; Angiboust et al. 2012b). The preserved garnet cores in the samples from the ISZ (eclogite ISZ17 and MVE5 and vein MVV4) have $\delta^{18} \mathrm{O}$ between 2 and $4 \%$ : these values are well below what expected for pristine mantle melts $(5.5 \pm 0.6 \%$ o, Eiler 2001) and indicate that the garnet grew in samples that had already low $\delta^{18} \mathrm{O}$ values. Notably, garnet in eclogite MVE5, which has limited evidence of HP metasomatism described in other Lago Superiore samples (Angiboust et al. 2011; Spandler et al. 2011; Angiboust et al. 2014), also has a low $\delta^{18} \mathrm{O}$. In this rock, garnet is the dominant phase and the bulk rock is expected to have a similarly low $\delta^{18} \mathrm{O}$. Previous studies have indeed demonstrated that in eclogites garnet is less than $0.5 \%$ o lighter than the bulk rock (Putlitz et al. 2000). The measured $\delta^{18} \mathrm{O}$ values of the garnet in the ISZ samples are in agreement with $\delta^{18} \mathrm{O}$ values of $3-5.3 \%$ from omphacite in metagabbro and HP veins of the same sequence (Nadeau et al. 1993). We propose that this pervasive metasomatism occurred by fluid-rock interaction at relatively high temperature at the ocean floor.

The bulk-rock $\delta^{18} \mathrm{O}$ profile across the Oman ophiolite shows that while at the surface pillow basalts have elevated $\delta^{18} \mathrm{O}$, further at depth $(4-5 \mathrm{~km})$ the altered mafic rocks (gabbros) can reach values as low as $\sim 3 \%$ due to hightemperature alteration with limited fluid/rock ratios (Gregory and Taylor 1981). Oxygen isotopic compositions below mantle values have also been reported in gabbros within the other ophiolitic sequences (4-8\%o, Miller et al. 2001). We thus concur with previous interpretations (Nadeau et al. 1993) that the Fe-Ti metagabbros in the Monviso ophiolite obtained their low $\delta^{18} \mathrm{O}$ during oceanic alteration at depth. Oceanic alteration may be expected to produce hydration in the protolith and subsequently eclogite that contains hydrous phases. Sample MVV5 only has traces of phengite $(<1 \%)$, but elsewhere along the ISZ eclogites are richer in hydrous minerals (e.g. Passo Gallarino sector, Angiboust et al. 2012b).
The alternative scenario that the low bulk $\delta^{18} \mathrm{O}$ of the Monviso metagabbros was caused by prograde fluids during subduction is less likely. The source for such low $\delta^{18} \mathrm{O}$ fluid would be other portions of altered oceanic basalts/ gabbros or serpentinites, as documented by previous studies (Spandler et al. 2011; Angiboust et al. 2014). However, the minimum $\delta^{18} \mathrm{O}$ of serpentinites is $3 \%$ (Gregory and Taylor 1981; Miller et al. 2002) and prograde alteration would require an unlikely total replacement of the oxygen in the eclogite to produce a bulk as low as $3 \%$. Therefore, we ascribe the low $\delta^{18} \mathrm{O}$ of the Monviso eclogite to oceanic alteration of the gabbros.

\section{High-pressure metasomatism}

The oxygen data on zircon and garnet provide constraints for two metasomatic events that occurred at eclogite facies: the vein formation and the fluid flux in the lower shear zone.

The identical $\delta^{18} \mathrm{O}$ values measured in garnet from vein MVV4 and eclogite MVE5 (Fig. 5) are in agreement with the omphacite data of Nadeau et al. (1993) and support their conclusion that the vein formed by circulation of fluids that were equilibrated with the surrounding eclogites. The very slight shift in $\delta^{18} \mathrm{O}$ between garnet core and rim measured in mylonitic eclogite ISZ17 could be simply due to local fractionation of oxygen or slight temperature and mineral mode variations between different stages of garnet growth. Such variation in oxygen isotopic composition at the outcrop scale was also reported for omphacite (Nadeau et al. 1993) and used to argue that complete homogenization at eclogite facies did not occur. The oxygen data are in line with some of the fluids being sourced from the serpentinites, as proposed by Spandler et al. (2011). In fact, fluids in equilibrium with the measured antigorite (3-3.6\%o) would precipitate garnet with $\delta^{18} \mathrm{O}$ around $2-3 \%$ at $\sim 600{ }^{\circ} \mathrm{C}$ (serpentine-water fractionation factors from Wenner 1979; Zheng 1993a).

The HP zircons found in the vein have $\delta^{18} \mathrm{O}$ values that are slightly more variable (1.6-3.6\%o) but largely overlapping with the garnets in veins and eclogites (2-3.8\%o) in the area. Zircon-garnet oxygen fractionation at 500 $600{ }^{\circ} \mathrm{C}$ - from first garnet growth to peak metamorphismis irrelevant (between 0.0 and $0.2 \%$ using fractionation factors from Zheng 1993b; Valley et al. 2003), and thus no significant difference in $\delta^{18} \mathrm{O}$ is expected between these two minerals at equilibrium. The age of metamorphic zircon in MVV4 (46 $\pm 1 \mathrm{Ma}$, Rubatto and Hermann 2003) constrains the Eocene vein formation.

Garnet in sample LSZ23 shows a more complex metasomatic history. As described in detail in Angiboust et al. (2011), the garnet core that first formed in the Monviso eclogites was fractured and partly recrystallized in a later 
stage, during prograde to peak metamorphism. The garnet rim formed close to the pressure peak followed by brecciation and dynamic recrystallization of omphacite and lawsonite in the matrix. The garnet core has remarkably low $\delta^{18} \mathrm{O}$ values of $0.2-2.0 \%$. The main difference between LSZ23 eclogite and the eclogites from the ISZ is the presence of Mg-rich chlorite. At $550{ }^{\circ} \mathrm{C}$, chlorite oxygen composition would be $1 \%$ heavier than garnet, but the sample only contains $\sim 5 \%$ chlorite and thus the bulk is still dominated by garnet and omphacite (together $90 \%$ of the bulk). These particularly low values in garnet are more likely due to some extreme alteration at the ocean floor, and possibly aggravated by alteration and interaction with serpentinite fluids during early metamorphism, as observed in the Corsican ophiolites (Miller and Cartwright 2000). These are the lowest $\delta^{18} \mathrm{O}$ values ever measured in metamorphic garnet in mafic rocks from the oceanic crust. Negative $\delta^{18} \mathrm{O}$ values ( -10 to $-1 \%$ ) have been reported only for eclogitic garnet within continental crust, where they are attributed to infiltration of meteoric or glacial water (Masago et al. 2003; Russell et al. 2013).

Particularly interesting is the shift to heavier oxygen from garnet core to garnet rim. A shift of $>3 \%$ cannot be produced by temperature and/or change in assemblage as none of these factors changed significantly from the first appearance of garnet to peak rim growth (Angiboust et al. 2011). A new metasomatic event must have occurred at this point, close to peak subduction. Although no zircon could be recovered from sample LSZ23, metamorphic zircon rims in nearby eclogite LSZ44 have $\delta^{18} \mathrm{O}$ values (1.9-3.8\%o) that are generally higher than the garnet core but lower than the garnet rim in LSZ23. Formation of metamorphic zircon is likely to be facilitated by fluids and deformation, and thus the $45.8 \pm 0.7 \mathrm{Ma}$ zircon rims in the shear zone most likely formed during mylonitization and metasomatism within the LSZ. By extrapolating the zircon data from sample LSZ44 to LSZ23, it can be suggested that this second metasomatic event occurred close in time to the growth of zircon at $\sim 46 \mathrm{Ma}$.

Such strong zoning in oxygen isotopes within garnet or any other metamorphic mineral has been rarely observed (Vielzeuf et al. 2005; Errico et al. 2013; Russell et al. 2013; Martin et al. 2014; Page et al. 2014) and in most cases in eclogite-facies samples. The marked difference in $\delta^{18} \mathrm{O}$ between garnet core and rim agrees with other studies showing that at temperatures $<600{ }^{\circ} \mathrm{C}$ diffusion of oxygen isotopes in garnet is insignificant over geological time scales (Vielzeuf et al. 2005; Russell et al. 2013; Martin et al. 2014; Page et al. 2014). The evolution of the Monviso eclogite with multiple metasomatic events due to oceanic alteration and high-pressure fluids is similar to what has been proposed for mafic rocks within the Franciscan Complex (Page et al. 2014). Also in that case garnet and zircons proved to be exceptional recorders of the fluid evolution with two stages of growth with distinct $\delta^{18} \mathrm{O}$.

\section{Fluid sources}

Serpentinites have often been suggested as source of fluids responsible for metasomatism during subduction because they have the capacity to liberate large amounts of water upon dehydration at depth. Antigorite dehydrates at $\sim 600-800{ }^{\circ} \mathrm{C}$ between 2 and 5 GPa (Ulmer and Trommsdorff 1995), where it liberates part of its 14 wt \% structural water. Evidence provided by oxygen and other light isotopes and trace element geochemistry support this scenario for Alpine eclogites (Spandler et al. 2011; Angiboust et al. 2014; Martin et al. 2014). The strong Ni, $\mathrm{Cr}$ and $\mathrm{Mg}$ enrichment visible in mineral and bulk-rock compositions (Spandler et al. 2011; Angiboust et al. 2014) clearly shows that serpentinite-derived fluids were present during metasomatism within the Monviso eclogite-facies shear zones. However, our results cannot be explained by pure serpentinite-derived fluids. Garnet rim in metasomatized eclogite LSZ23 is in equilibrium with water with a $\delta^{18} \mathrm{O}$ of $6.5-9 \%$, and thus the fluid source must be isotopically heavier than the serpentinites. The Monviso serpentinites have low $\delta^{18} \mathrm{O}$ of 3.0-3.6\% (Fig. 8). At temperatures of garnet rim growth $\left(550{ }^{\circ} \mathrm{C}\right)$, fluids released from such serpentinites would have a $\delta^{18} \mathrm{O}$ of around 4.6-5.9\%o depending on the serpentine-water fractionation factor used (Wenner and Taylor 1971; Zheng 1993a). At higher temperatures, closer to the antigorite dehydration reaction, released fluids would be even lighter in oxygen isotope composition. Thus fluids from serpentinites would be too light in oxygen isotopes to produce the shift from garnet core to rim $(0.2-2.0$ to $3.5-6.0 \%$ ).

In the Lago Superiore Unit sequence, the only rocks with a sufficiently heavy oxygen isotopic signature are metasediments. Whereas no bulk-rock data exist for the Monviso sediments, sediments from other units of subducted oceanic crust that outcrop along the Alpine belt have $\delta^{18} \mathrm{O}$ in the range 14-26\%o (Miller et al. 2001; CookKollars et al. 2014) with coexisting water having $\delta^{18} \mathrm{O}$ of 9-16\%o (Bebout and Barton 1989). We thus propose that partial metasomatism from such heavy fluids, close to the peak of metamorphism, was responsible for the shift in oxygen recorded in LSZ23 garnet.

Other indications that sediment-derived fluids contributed to the metasomatic event reported in the LSZ are given in Angiboust et al. (2014). Eclogite samples from the LSZ, including LSZ23 and LSZ44, are enriched in Cs, Rb and Ba with respect to ISZ metagabbros and the serpentinite sole. These elements are comparatively water soluble and abundant in metasediments (see Global Subducting Sediments in Plank and Langmuir 1998). 
Sediments are capable of transporting significant amounts of water to great depth (Hermann and Rubatto 2014), but also liberate $80 \%$ of their water at fore-arc depths $(<4 \mathrm{GPa})$ either by pore water expulsion during compaction, or at mantle depth by dehydration (Schmidt and Poli 1998; Hacker 2008). The modelling of Angiboust and Agard (2010) for a pelite subducted along the cold Alpine geotherm $\left(350-650^{\circ} \mathrm{C}\right.$ from 1.0 to $3.0 \mathrm{GPa}$ ) shows that Alpine metasediments lost $\sim 3 \mathrm{wt} \%$ water at temperatures of $450-600{ }^{\circ} \mathrm{C}$ when the modal proportion of garnet increased substantially (see also calculations by Baxter and Caddick 2013). This modelling provides further evidence that the nearby dehydrating metasediments probably contributed to the significant metasomatism observed along the LSZ.

Metasomatism by sediment-derived fluids has been extensively documented in the Catalina Schists (Bebout and Barton 1989), a terrane that is particularly rich in metasediments and where the pillow basalts show ample evidence of deep sea floor alteration. More cryptic interaction with sediment-derived fluids during subduction has been proposed for the eclogitic blocks within the Franciscan Complex, which also contain garnet domains enriched in $\delta^{18} \mathrm{O}$ (Errico et al. 2013). Localized interaction of fluids derived from metasediments with serpentinites has been postulated for the Zermatt-Saas ophiolite on the basis of $\mathrm{Cl}$ isotopes (Selverstone and Sharp 2013). In these reported cases, the mafic rocks are hosted within a sedimentary-rich matrix. In the Monviso Lago Superiore Unit however, the relative scarcity of metasediments along the LSZ (2-3\% metasediments, $90 \%$ serpentinite, 7-8 \% mafics; Lombardo et al. 1978; Angiboust et al. 2011; Balestro et al. 2013) implies that local dehydration of metasediments cannot account for pervasive metasomatism. Instead metasomatism occurred at the loci of fluid concentration along major fluid channels such as the LSZ (Angiboust et al. 2014) where fluids from the dehydrating oceanic lithosphere (namely sediments and serpentinite) were mixed during subduction.

\section{Conclusions and implications for subduction processes}

The P-T-time-fluid path reconstructed here for the Lago Superiore metagabbros reveals that the nature of fluid-rock interaction during burial of oceanic lithosphere is complex and probably comprises multiple, discrete stages involving both sediment-derived and serpentinite-derived fluids. Such multistage evolution is best captured at the mineral scale using diverse geochemical indicators. Oxygen isotopes, trace element geochemistry (Spandler et al. 2011) and B isotopes (Angiboust et al. 2014) point to the existence of multiple fluid-rock interaction events from the ocean floor to deep subduction. Gabbros acquired light oxygen isotopic signatures by hydrothermal alteration at relatively high temperature in the oceanic crust. The first metamorphic minerals to form (e.g. garnet core) inherit such low $\delta^{18} \mathrm{O}$. At high pressure, fluid pulses are channelized within shear zones along lithostratigraphic boundaries such as the LSZ. The channelization may allow minor sediment-derived fluids to be sufficiently concentrated to produce metasomatism that leaves a distinct heavy $\delta^{18} \mathrm{O}$ signature and enrichment of LILE (Angiboust et al. 2014). In such an altered oceanic sequence, interaction during subduction with fluids generated from serpentinite dehydration with low $\delta^{18} \mathrm{O}$ will not significantly shift the oxygen isotopes and is best investigated by mineral trace elements or alternative isotopic systems (Spandler et al. 2011; Angiboust et al. 2014).

Our geochronological investigations yielded identical ages of 45-46 Ma, for both ISZ eclogites and LSZ metasomatized eclogites. These new data combined with textural arguments show that (1) mylonitization along the ISZ, (2) brecciation of ISZ metagabbros, and (3) formation of the metasomatic rinds along LSZ blocks likely took place in a time frame shorter than 1 million years. These results, together with recent observations by Dragovic et al. (2012) and John et al. (2012), confirm that fluid-rock interaction in subduction zones can take place over relatively short periods of time of $10^{3}-10^{5}$ years.

Acknowledgments This study benefited from constructive discussion with Joerg Hermann. D Rubatto acknowledges the financial support of the Australia Research Council, DP110101599.

\section{References}

Angiboust S, Agard P (2010) Initial water budget: the key to detaching large volumes of eclogitized oceanic crust along the subduction channel? Lithos 120:453-474

Angiboust S, Agard P, Raimbourg H, Yamato P, Huet B (2011) Subduction interface processes recorded by eclogite-facies shear zones (Monviso, W. Alps). Lithos 127:222-238

Angiboust S, Agard P, Yamato P, Raimbourg H (2012a) Eclogite breccias in a subducted ophiolite: a record of intermediate depth earthquakes? Geology 40:707-710

Angiboust S, Langdon R, Agard P, Waters D, Chopin C (2012b) Eclogitization of the Monviso ophiolite (W. Alps) and implications on subduction dynamics. J Metamorph Geol 30:37-61

Angiboust S, Pettke T, De Hoog JCM, Caron B, Oncken O (2014) Channelized fluid flow and eclogite-facies metasomatism along the subduction shear zone. J Petrol 55:883-916

Ayers JC, Loflin M, Miller CF, Barton MD, Coath CD (2006) In situ oxygen isotope analysis of monazite as a monitor of fluid infiltration during contact metamorphism: Birch Creek Pluton aureole, White Mountains, eastern California. Geology 34:653-656

Balestro G, Fioraso G, Lombardo B (2013) Geological map of the Monviso Massif (Western Alps). J Maps 9:623-634

Baxter EF, Caddick MJ (2013) Garnet growth as a proxy for progressive subduction zone dehydration. Geology 41:643-646 
Bebout GE, Barton MD (1989) Fluid flow and metasomatism in a subduction zone hydrothermal system: Catalina Schist terrane, California. Geology 17:976-980

Black LP, Kamo SL, Allen CM, Aleinikoff JM, Davis DW, Korsch RJ, Foudoulis C (2003) TEMORA 1: a new zircon standard for Phanerozoic U-Pb geochronology. Chem Geol 200:155-170

Cartwright I, Barnicoat AC (1999) Stable isotope geochemistry of Alpine ophiolites: a window to ocean-floor hydrothermal alteration and constraints on fluid-rock interaction during high-pressure metamorphism. J Earth Sci 88:219-235

Cook-Kollars J, Bebout GE, Collins NC, Angiboust S, Agard P (2014) Subduction zone metamorphic pathway for deep carbon cycling: I. Evidence from HP/UHP metasedimentary rocks, Italian Alps. Chem Geol 386:31-48

Dragovic B, Samanta LM, Baxter EF, Selverstone J (2012) Using garnet to constrain the duration and rate of water-releasing metamorphic reactions during subduction: an example from Sifnos, Greece. Chem Geol 314-317:9-22

Eiler JM (2001) Oxygen isotope variations of basaltic lavas and upper mantle rocks. In: Valley JW, Cole DR (eds) Stable isotope geochemistry, vol 43. Mineralogical Society of America, Washington

Eiler JM, Valley JW, Graham CM, Baumgartner LP (1995) Ion microprobe evidence for the mechanisms of stable isotope retrogression in high-grade metamorphic rocks. Contrib Mineral Petrol 118:365-378

Errico JC, Barnes JD, Strickland A, Valley JW (2013) Oxygen isotope zoning in garnets from Franciscan eclogite blocks: evidence for rock-buffered fluid interaction in the mantle wedge. Contrib Mineral Petrol 166:1161-1176

Früh-Green G, Scambelluri M, Vallis F (2001) O-H isotope ratios of high pressure ultramafic rocks: implications for fluid sources and mobility in the subducted hydrous mantle. Contrib Mineral Petrol 141:145-159

Gregory RT, Taylor HP (1981) An oxygen isotope profile in a section of Cretaceous Oceanic Crust, Samail Ophiolite, Oman: evidence for $\delta 180$ buffering of the oceans by deep ( $>5 \mathrm{~km}$ ) seawaterhydrothermal circulation at mid-ocean ridges. J Geophys Res 86:2737-2755

Groppo C, Castelli D (2010) Prograde P-T evolution of a lawsonite eclogite from the Monviso meta-ophiolite (Western Alps): dehydration and redox reactions during subduction of oceanic FeTioxide gabbro. J Petrol 51:2489-2514

Hacker BR (2008) H2O subduction beyond arcs. G3. Geochem Geophys Geosyst 9:1-24

Harlov DE, Austrheim H (2013) Metasomatism and the chemical transformation of rocks. Springer, Berlin, $\mathrm{p} 789$

Hermann J, Rubatto D (2014) Subduction of continental crust to mantle depth: geochemistry of ultrahigh-pressure rocks. In: Rudnick R (ed) The crust, vol 4. Elsevier, Amsterdam, pp 309-340

Hermann J, Zheng YF, Rubatto D (2013) Deep fluids in subducted continental crust. Elements 9:281-287

Hoefs J (2004) Stable isotope geochemistry. Tokyo, Springer, p 244

Ickert RB, Hiess J, Williams IS, Holden P, Ireland TR, Lanc P, Schram N, Foster JJ, Clement SW (2008) Determining high precision, in situ, oxygen isotope ratios with a SHRIMP II: analyses of MPI-DING silicate-glass reference materials and zircon from contrasting granites. Chem Geol 257:114-128

Jamtveit B, Austrheim H (2010) Metamorphism: the role of fluids. Elements 6:153-158

John T, Gussone N, Podladchikov YY, Bebout GE, Dohmen R, Halama R, Klemd R, Magna T, Seitz HM (2012) Volcanic arcs fed by rapid pulsed fluid flow through subducting slabs. Nat Geosci 5:489-492

Lombardo B, Nervo R, Compagnoni R, Messiga B, Kienast JR, Mevel C, Fiora L, Piccardo GB, Lanza R (1978) Osservazioni preliminari sulle ofioliti metamorfiche del Monviso (Alpi Occidentali). Rend Soc Ital Mineral Petrol 34:253-305

Ludwig KR (2003) Isoplot/Ex version 3.0. A geochronological toolkit for Microsoft Excel. In: Berkeley Geochronological Centre Special Publication, Berkeley, p 70

Manatschal G, Müntener O (2009) A type sequence across an ancient magma-poor ocean-continent transition: the example of the western Alpine Tethys ophiolites. Tectonophysics 473:4-19

Martin L, Ballevre M, Boulvais P, Halfpenny A, Vanderhaeghe O, Duchêne S, Deloule E (2011) Garnet re-equilibration by coupled dissolution-reprecipitation: evidence from major element and oxygen isotope zoning of "cloudy" garnet. J Metamorph Geol 29:213-231

Martin L, Rubatto D, Crepisson C, Hermann J, Putlitz B, Vitale-Brovarone A (2014) Garnet oxygen analysis by SHRIMP-SI: matrix corrections and application to high pressure metasomatic rocks from Alpine Corsica. Chem Geol 374-375:25-36

Masago H, Rumble D, Ernst WG, Parkinson CD, Maruyama S (2003) Low d180 eclogites from the Kokchetav massif, northern Kazakhstan. J Metamorph Geol 21:579-587

Miller JA, Cartwright I (2000) Distinguishing between seafloor alteration and fluid flow during subduction using stable isotope geochemistry: examples from Tethyan ophiolites in the Western Alps. J Metamorph Geol 18:467-482

Miller JA, Cartwright I, Buick I, Barnicoat A (2001) An O-isotope profile through the HP-LT Corsican ophiolite, France and its implications for fluid flow during subduction. Chem Geol 178:43-69

Miller CF, Buick IS, Cartwright I, Barnicoat A (2002) Fluid processes during the exhumation of high-P metamorphic belts. Miner Mag 66:93-119

Nadeau S, Philippot P, Pineau F (1993) Fluid inclusion and mineral isotopic compositions $(\mathrm{H}-\mathrm{O}-\mathrm{C})$ in eclogitic rocks as tracers of local fluid migration during high-pressure metamorphism. Earth Planet Sci Lett 114:431-448

Padrón-Navarta JA, Sánchez-Vizcaíno VL, Garrido CJ, Gómez-Pugnaire MT (2011) Metamorphic record of high-pressure dehydration of antigorite serpentinite to chlorite harzburgite in a subduction setting (Cerro del Almirez, Nevado-Filábride complex, Southern Spain). J Petrol 52:2047-2078

Page FZ, Kita NT, Valley JW (2010) Ion microprobe analysis of oxygen isotopes in garnets of complex chemistry. Chem Geol 270:9-19

Page FZ, Essene EJ, Mukasa SB, Valley JW (2014) A garnet-zircon oxygen isotope record of subduction and exhumation fluids from the Franciscan complex, California. J Petrol 55:103-131

Philippot P (1993) Fluid-melt rock interaction in mafic eclogites and coesite-bearing metasediments-constraints on volatile recycling during subduction. Chem Geol 108:93-112

Plank T, Langmuir CH (1998) The chemical composition of subducting sediments and its consequences for the crust and mantle. Chem Geol 145:325-394

Putlitz B, Matthews A, Valley JW (2000) Oxygen and hydrogen isotope study of high-pressure metagabbros and metabasalts (Cyclades, Greece): implications for the subduction of oceanic crust. Contrib Mineral Petrol 138:114-126

Raimondo T, Clark C, Hand M, Cliff J, Harris C (2012) High-resolution geochemical record of fluid-rock interaction in a mid-crustal shear zone: a comparative study of major element and oxygen isotope transport in garnet. J Metamorph Geol 30:255-280

Rubatto D, Hermann J (2003) Zircon formation during fluid circulation in eclogites (Monviso, Western Alps): implications for $\mathrm{Zr}$ and Hf budget in subduction zones. Geochim Cosmochim Acta 67:2173-2187

Russell AK, Kitajima K, Strickland A, Medaris LG Jr, Schulze DJ, Valley JW (2013) Eclogite-facies fluid infiltration: 
constraints from $\mathrm{d} 18 \mathrm{O}$ zoning in garnet. Contrib Mineral Petrol 165:103-116

Schmidt MW, Poli S (1998) Experimentally based water budgets for dehydrating slabs and consequences for arc magma generation. Earth Planet Sci Lett 163:361-379

Selverstone J, Sharp ZD (2013) Chlorine isotope constraints on fluidrock interactions during subduction and exhumation of the Zermatt-Saas ophiolite. Geochem Geophys Geosyst 14:4370-4391. doi:10.1002/ggge.20269

Spandler C, Pettke T, Rubatto D (2011) Internal and external fluid sources for eclogite-facies veins in the Monviso meta-ophiolite, Western Alps: implications for fluid flow in subduction zones. J Petrol 52:1207-1236

Stacey JS, Kramers JD (1975) Approximation of terrestrial lead evolution by a two-stage model. Earth Planet Sci Lett 26:207-221

Ulmer P, Trommsdorff V (1995) Serpentine stability to mantle depths and subduction-related magmatism. Science 268:858-861

Valley JW (2003) Oxygen isotopes in zircon. In: Hanchar JM, Hoskin PWO (eds) Zircon, vol 53. Mineralogical Society of America, Washington, pp 343-385

Valley JW, Kitchen N, Kohn MJ, Niendorf CR, Spicuzza MJ (1995) UWG-2, a garnet standard for oxygen isotope ratios: strategies for high precision and accuracy with laser heating. Geochim Cosmochim Acta 59:5223-5231

Valley JW, Kinny PD, Schulze DJ, Spicuzza MJ (1998) Zircon megacrysts from kimberlite: oxygen isotope variability among mantle melts. Contrib Mineral, Petrol

Valley JW, Bindeman IN, Peck WH (2003) Empirical calibration of oxygen isotope fractionation in zircon. Geochim Cosmochim Acta 67:3257-3266
Vielzeuf D, Veschambre M, Brunet F (2005) Oxygen isotope heterogeneities and diffusion profile in composite metamorphic-magmatic garnets from the Pyrenees. Am Mineral 90:463-472

Wenner DB (1979) Hydrogen, oxygen and carbon isotopic evidence for the origin of rodingites in serpentinized ultramafic rocks. Geochim Cosmochim Acta 43:603-614

Wenner DB, Taylor HP (1971) Temperatures of serpentinization of ultramafic rocks based on 018/016 fractionation between coexisting serpentine and magnetite. Contrib Mineral Petrol $32: 165-185$

Whitney DL, Evans BW (2010) Abbreviations for names of rockforming minerals. Am Mineral 95:185-187

Williams IS (1998) U-Th-Pb geochronology by ion microprobe. In: McKibben MA, Shanks WC III, Ridley WI (eds) Application of microanalytical techniques to understanding mineralizing processes, vol 7. Reviews in economic geology. Society of Economic Geologists, Littleton, pp 1-35

Yardley BWD (2009) The role of water in the evolution of the continental crust. J Geol Soc 166:585-600

Zheng YF (1991) Calculation of oxygen isotope fractionation in metal oxides. Geochim Cosmochim Acta 55:2299-2307

Zheng YF (1993a) Calculation of oxygen isotope fractionation in hydroxyl-bearing silicates. Earth Planet Sci Let. 120:247-263

Zheng YF (1993b) Calculation of oxygen isotope fractionation in anhydrous silicate minerals. Geochim Cosmochim Acta 57:1079-1091 